\title{
ANALYSIS OF THE COEFFICIENT OF VARIATION IN SHEAR AND TENSILE BOND STRENGTH TESTS
}

\author{
ANÁLISE DO COEFICIENTE DE VARIAÇÃO EM TESTES DE RESISTÊNCIA DA UNIÃO AO \\ CISALHAMENTO E TRAÇÃO
}

Fábio Lourenço ROMANO ${ }^{1}$, Gláucia Maria Bovi AMBROSANO', Maria Beatriz Borges de Araújo MAGNANI ${ }^{1}$, Darcy Flávio NOUER ${ }^{1}$

\begin{abstract}
1- MSc, Assistant Professor, Department of Orthodontics, Alfenas Pharmacy and Dental School - Efoa/Ceufe, Minas Gerais, Brazil.
2- DDS, MSc, Associate Professor of Biostatistics, Department of Social Dentistry, Piracicaba Dental School - UNICAMP, São Paulo, Brazil; CNPq researcher.

3- DDS, MSc, Assistant Professor of Orthodontics, Department of Child Dentistry, Piracicaba Dental School - UNICAMP, São Paulo, Brazil. 4- DDS, MSc, Full Professor of Orthodontics, Department of Child Dentistry, Piracicada Dental School - UNICAMP, São Paulo, Brazil.
\end{abstract}

Corresponding address: Fábio Lourenço Romano - Avenida do Café, 131 Bloco E, Apartamento 16 - Vila Amélia - Ribeirão Preto - SP Cep.: 14050-230 - Phone: (16) 6366648 - e-mail: flromano@aol.com

Received: July 29, 2004 - Modification: September 09, 2004 - Accepted: June 07, 2005

\begin{abstract}
$T_{\mathrm{h}}$

Le coefficient of variation is a dispersion measurement that does not depend on the unit scales, thus allowing the comparison of experimental results involving different variables. Its calculation is crucial for the adhesive experiments performed in laboratories because both precision and reliability can be verified. The aim of this study was to evaluate and to suggest a classification of the coefficient variation (CV) for in vitro experiments on shear and tensile strengths. The experiments were performed in laboratory by fifty international and national studies on adhesion materials. Statistical data allowing the estimation of the coefficient of variation was gathered from each scientific article since none of them had such a measurement previously calculated. Excel worksheet was used for organizing the data while the sample normality was tested by using Shapiro Wilk tests $(\alpha=0.05)$ and the Statistical Analysis System software (SAS). A mean value of 6.11 (SD = 1.83) for the coefficient of variation was found by the data analysis and the data had a normal distribution $(\mathrm{p}>0.05)$. A range classification was proposed for the coefficient of variation from such data, that is, it should be considered low for a value lesser than 2.44; intermediate for a value between 2.44 and 7.94, high for a value between 7.94 and 9.78, and finally, very high for a value greater than 9.78. Such classification can be used as a guide for experiments on adhesion materials, thus making the planning easier as well as revealing precision and validity concerning the data.

Uniterms: Statistic; Shear strength; Tensile strength.
\end{abstract}

\begin{abstract}
RESUMO
$\mathrm{O}$

Coeficiente de variação é uma medida de dispersão que independe da escala de unidades, permitindo comparação de resultados experimentais de variáveis diferentes. Seu cálculo é imprescindível em experimentos laboratoriais de adesão, pois a partir dele é possível verificar a precisão e confiabilidade do experimento. O objetivo deste trabalho foi avaliar e sugerir uma classificação do coeficiente de variação $(\mathrm{CV})$ em experimentos in vitro que envolveram testes de resistência ao cisalhamento e / ou tração. Foram analisados 50 trabalhos de periódicos nacionais e internacionais, sendo que todos avaliaram a adesão em ensaios laboratoriais. Foram coletados em cada artigo dados estatísticos que permitiram estimar o coeficiente de variação, pois nenhum deles apresentava esta medida calculada. Os dados coletados foram organizados em Planilha Excel, sendo a normalidade da amostra testada pelo teste de Shapiro Wilk $(\alpha=0,05)$ utilizando o programa Statistical Analysis System (SAS). Pela análise dos dados, tendo os mesmos apresentados distribuição normal ( $p>0,05$ ) foi encontrado um CV médio de 6,11 com desviopadrão de 1,83. A partir destes dados foram propostas faixas de classificação para o coeficiente de variação, ou seja, este coeficiente deve ser considerado baixo até um valor de 2,44; médio entre 2,44 - 7,94, alto entre 7,94 - 9.78 e muito alto acima de 9,78. Esta classificação poderá ser usada como guia para experimentos de adesão, facilitando o planejamento, revelando a precisão e validade dos dados.

Unitermos: Estatística; Resistência ao cisalhamento; Resistência à tração.
\end{abstract}




\section{INTRODUCTION}

The experiments testing materials used for bonding devices to dental enamel are greatly represented in the orthodontic literature where various types of materials (e.g. composites, glass ionomer cements, compomers) are evaluated by in vitro tests on both shear and tensile strengths.

The results from such experiments are usually extrapolated to the orthodontic clinic according to the successful use of certain materials. Despite the great concern with the scientific quality, however, such orthodontic articles have been published with low experimental precision in large part due to the lack of reference values for comparison.

Statistical softwares are used for analyzing the data obtained from such experiments, where mean values and standard deviations are assessed. Nevertheless, such researches have a great diversity in terms of project and as a result the researchers also need to evaluate the dispersion measurement called coefficient of variation (CV) in order to asses both the experiment's precision and the data's reliability since those studies carried out with low precision usually result in mistaken conclusions ${ }^{1-3}$.

The coefficient of variation allows the comparison between experimental data without the need of equaling the units $^{4}$ and such a coefficient can be calculated by the following formula: $\mathrm{CV}=\mathrm{S} / \mathrm{Y}$ multiplied by 100 , where $\mathrm{S}$ is the standard deviation and $\mathrm{Y}$ is the mean value ${ }^{5-9}$.

The CV calculation is extremely important for the researchers who want to quantify the precision of their scientific work because this relative measurement of variation enables the comparison of different experiments involving the same variable/response ${ }^{1}$. Despite this ideal measurement of variation for data series involving different units $^{6}$, Graner ${ }^{10}$ emphasizes that it should not be employed in a generalized way, such as comparisons involving extremely distinct magnitudes. CV is also used for determining sample sizes as well as for estimating the population average ${ }^{9,11,12}$.

In addition, the $\mathrm{CV}$ calculation becomes essential for any experiment because the sample size can be planned ${ }^{13}$ and as a result the amount of samples necessary for carrying out the study can be determined as well. By using such a measurement it is possible to verify the methodological process comparing the number of representative repetitions in order to assess the material adhesiveness to the tooth.

In face of such considerations, the aim of this study was to evaluate and to suggest the distribution of the coefficient of variation, which was ranked into low, intermediate, high, and very high for the adhesion experiments involving both shear and tensile bond strength tests.

\section{MATERIALAND METHOD}

Fifty national and international scientific articles from 16 dental periodicals published between 1990 and 2003 (Table 1) were evaluated. All the articles involved in vitro tests on shear and tensile bond strengths.

Because none of the studies had shown coefficient of variation tests, statistical data allowing the calculation of such measurement were gathered (mean values and standard deviations).

The articles evaluated by this study involved in vitro experiments on shear and/or tensile bond strength to the tooth structure using different adhesive materials and several types of brackets.

The information gathered was inserted into Excel worksheets and organized for defining the mean coefficients as well as the frequency classes.

The normality of the coefficients of variation were tested through Shapiro-Wilk tests ${ }^{14}$ using the Statistical Analysis

TABLE 1- Periodicals from which the articles were selected

\begin{tabular}{ll}
\hline \multicolumn{1}{c}{ Periodicals } & Quantity \\
\hline American Journal Dentistry & 1 \\
American Journal of Orthodontics and Dentofacial Orthopedics & 21 \\
Angle Orthodontics & 3 \\
European Journal of Orthodontics & 2 \\
Jornal Brasileiro de Ortodontia e Ortopedia Facial & 5 \\
Journal Clinical of Orthodontics & 1 \\
Journal of Orthodontics & 1 \\
Ortodontia & 2 \\
Pesquisa Odontológica Brasileira & 1 \\
Quintessence International & 1 \\
Revista Brasileira de Ortodontia & 1 \\
Revista da ABO nacional & 1 \\
Revista da Associação Paulista de Cirurgiões-Dentista & 3 \\
Revista da Faculdade de Odontologia de Bauru & 1 \\
Revista da Sociedade Brasileira de Ortodontia & 1 \\
Revista Dental Press de Ortodontia e Ortopedia Facial & 5 \\
\hline
\end{tabular}


System software (SAS).

Next, the coefficients of variation were classified according to the criterion proposed by Garcia ${ }^{15}$ as follows:

Low: $\mathrm{CV} \leq \mathrm{y}-\mathrm{s}$

Intermediate: $\mathrm{y}-\mathrm{s}<\mathrm{CV} \leq \mathrm{y}+\mathrm{s}$

High: $\mathrm{y}+\mathrm{s}<\mathrm{CV} \leq+2 \mathrm{~s}$

Very High: $\mathrm{CV}>\mathrm{y}+2 \mathrm{~s}$

Where $\mathrm{y}=$ mean value for $\mathrm{CV}$ and $\mathrm{s}=$ standard deviation for $\mathrm{CV}$

\section{RESULTS AND DISCUSSION}

All the articles evaluated by this study involved shear and/or tensile strength tests using adhesive materials. The number of repetitions in each group varied between 5 and 40 times and all articles had their statistical data analyzed.

All the studies also presented mean values for the groups, but five of them had no standard deviation and only 50\% presented data graphically demonstrated.

The variation of experimental data can be expressed by dispersion measurements: standard error average, variance $\left(\mathrm{s}^{2}\right)$ and coefficient of variation. As it was mentioned before, calculating the coefficient of variation $(\mathrm{CV})$ is of great importance in evaluating the outcome precision from any study. Although 50 articles had been analyzed, there was no $\mathrm{CV}$ calculation at all. Because of the lack of $\mathrm{CV}$ the researchers have difficulty in evaluating the precision of their experiments.

In order to acknowledge if the experiment has an adequate degree of precision and also to facilitate the future planning, this study has suggested CV values since the satisfactory planning enables the estimation of the number of samples, thus both time and money can be saved. The data gathered from the articles had a normal pattern of distribution when tested by using Shapiro-Wilk tests ${ }^{14}(\mathrm{p}>0.05)$. The coefficient of variation had the following values: mean value of 6.11 with standard deviation of 1.83 . From such data, a classification of the coefficient of variation could be established (Table 2). The coefficient was considered low for values lesser than 2.44; intermediate for values between 2.44 and 7.94; high for values between 7.94 and 9.78, and very high for values greater than 9.78.

Differences between treatments may not be detected in experiments involving high $\mathrm{CV}$ values because of either the heterogeneity of experimental material or the method of conducting the research ${ }^{13}$. The smaller is the $\mathrm{CV}$ value, the greater is the data homogeneity and the smaller is the variation $^{15}$

Quantifying the magnitude of the experimental error is

TABLE 2- Classification of the Coefficient of Variation (CV)

\begin{tabular}{cc}
\hline Index & CV range \\
\hline Low & Less than 2.44 \\
Intermediate & Between 2.44 and 7.94 \\
High & Between 7.94 and 9.78 \\
Very High & Greater than 9.78 \\
\hline
\end{tabular}

one of the ways of evaluating the experiment quality, which indicates how the causal variability was controlled and how it affected the precision of statistical measurement ${ }^{1}$. Despite the concern with quality, most studies without the necessary precision have been published because of the lack of adequate reference values for performing comparison between the variables. Such a fact has prevented some articles from being published because of the incorrect evaluation $^{1,5}$.

By using such a CV classification the researchers studying adhesion materials will have a parameter for comparing their experiments as well as for calculating the statistical value of their samples. The researchers will also have the possibility of estimating the number of samples to be correctly used for representing the adhesive strength of the materials.

\section{CONCLUSION}

The establishment of such classification for the coefficient of variation will enable the researchers to plan and verify both precision and reliability of the experiments involving adhesion materials and shear/tensile strength tests. The laboratory tests will be more reliable and more easily comparable by carrying out studies according to these criteria previously established.

\section{REFERENCES}

1- Judice MG, Muniz JA, Aquino LH, Bearzotti E. Evaluation of experimental precision in beef cattle experiments. Cienc Agrotecnol. 2002;26:1035-40.

2- Steel RGD, Torrie JH. Principles and procedures of statistics, with special reference to the Biological Sciences. New York: McGrawHill;1980.

3- Thompson SK. Sampling. New York: Wiley-Interscience; 1992.

4- Amaral AM, Muniz JA, Souza M. Avaliação do Coeficiente de Variação como medida da precisão na experimentação com citros Pesq Agropec Brasileira. 1997;32:1221-5.

5- Meyer P. Introductory probability and statistical applications. Massachusetts: Wesley; 1966.

6- Christensen R. Analysis of variance, design and regression. New York: Chapman \& Hall; 1995.

7- Bunchaft G, Kellner SRO. Estatística sem mistérios. São Paulo: Editora Vozes; 2002.

8- Cody RP, Smith JK. Applied statistics and the SAS programming language. New Jersey: Prentice Hall; 1997.

9- Sheskin DJ. Handbook of parametric and no-parametric statistical procedures. New York: Chapman e Hall; 2004.

10- Graner EA. Estatística. São Paulo: Melhoramentos; 1996.

11- Sokal RR, Rohlf FJ. Introduction to biostatistics. New York: WH Freeman and Company; 1973. 
12-Gupta S, Singh KS. Estimation of population mean using coefficient of variation and auxiliary information. Braz J Probab Stat. 1998;12:35-40.

13- Federer WT. Experimental design. New York: John Wiley; 1957.

14- Shapiro SS, Wilk MB. An analysis of variance test for normality (complete samples). Biometrika. 1965;52:591-611.

15- Garcia CH. Tabelas para classificação do coeficiente de variação., Piracicaba: IPEF; 1989. 12p. [Circular Técnica, 171]. 